\title{
MODELING TOURISTS' SATISFACTION IN THE NATURE-BASED TOURIST DESTINATION USING STRUCTURAL EQUATION MODELING TECHNIQUE
}

\author{
Md. Shakhawat HOSSAIN* \\ Jagannath University, Department of Management Studies, Bangladesh and \\ University of Barishal, Department of Management Studies, Bangladesh, e-mail: abir.md@gmail.com \\ Md. Golam MOSTAFA \\ Jagannath University, Department of Management Studies, Bangladesh, e-mail: mostafajnu@ yahoo.com
}

Md. Alamgir HOSSAIN

Hajee Mohammad Danesh Science and Technology University, Department of Management, Bangladesh, e-mail: shamimru@gmail.com

\begin{abstract}
Citation: Hossain, M.S, Mostafa, M.G., \& Hossain, M.A. (2021). MODELING TOURISTS' SATISFACTION IN THE NATURE-BASED TOURIST DESTINATION USING STRUCTURAL EQUATION MODELING TECHNIQUE. GeoJournal of Tourism and Geosites, 37(3), 814-822. https://doi.org/10.30892/gtg.37311-713
\end{abstract}

\begin{abstract}
The goal of this study is to show how satisfied tourists is of supreme significance to the tourism industry, particularly as it affects the future of a nature-based destination and explores the relationship among destination image, service quality, perceived value, tourist satisfaction, word-of-mouth, and revisit intentions of tourists. The 292 survey data was obtained via a structured questionnaire from tourists who visited the Haor region, Bangladesh and structural equation modeling (SEM) is used to test the hypothetical paths. Six hypotheses were accepted, and one is rejected. Tourism stakeholders can find important knowledge and they can satisfy tourists, which is likely by improving destination.
\end{abstract}

Key words: Tourism, Modeling, SEM, Tourist, Satisfaction, Natural-Destination

\section{INTRODUCTION}

In tourism, tourist satisfaction is an important research topic for academics and all stakeholders (Wang et al., 2009). Considering local tourists' satisfaction towards tourist destinations and factors that might affect their satisfaction is essential to know the achieving the best output for tourism development (Yoon et al., 2001). Understanding tourists' satisfaction is of supreme significance to the tourism industry, particularly as it affects the future economy (Hossain et al., 2015). The tourism sector has the potentiality to become the heart of the development of the Bangladeshi economy. WTTC (2020), claimed that the cumulative contribution of travel and tourism to Bangladesh's GDP in 2019 was USD 9,113.2 million which is 3.0 percent of the total economy. On the other hand, contribution towards employment was 1,858.9 JOBS (000's), which is 2.9 percent of entire employment. The world's longest 120 kilometers long sandy beach Cox's Bazar (Hossain, 2013), St. Martin, a small coral island about 10 km (Rahaman, 2009), Sundarban, a UNESCOdesignated world heritage site, Haor region, Hill tracts, Sylhet, and Kuakata have all made significant contributions to Bangladesh's tourism sector. Among all tourist destinations, Haors are unique wetlands that have the potential for pulling in sightseers (CEGIS, 2012). For tourism service providers at the destination should consider that the satisfied and happy visitors return to a destination and spread positive word of mouth (Buonincontri et al., 2017). There is a substantial amount of literature published which discusses tourists' satisfaction, destination attributes/ services in the different country context (Kozak, 2001; Viet, 2019; Joppe et al., 2001; Cong, 2016; Le and Dong, 2017).

Constructions and their interrelationships were most frequently borrowed from established literature that was evaluated in Western and European cultures through tourism services and satisfaction surveys. For Least Developed Countries (LDCs) such as Bangladesh, these may be distinct because of their cultural diversification (Hossain, 2013). Furthermore, while researchers have attempted to build models to classify the variables that contribute to tourist satisfaction, minimal work has been done to advance the theoretical formation of Bangladeshi domestic tourists' satisfaction with tourism facilities, revisit, and word-of-mouth intentions in the nature-based destinations. These gaps have created an excellent room for new research into creating an all-encompassing service quality, destination image, perceived value, tourist satisfaction, word of mouth, and revisit intentions model that could enable destination operators to reflect on the essential factors that lead to domestic visitors' satisfaction and increase revisit and word-of-mouth intentions towards the nature-based destination. So, the objective of this research is to see how a destination's image, service quality, and perceived value impact tourists' satisfaction and, as a result, how the behavior of tourists such as word-of-mouth and return visits to a natural-based destination are formed. This study constructs an immersive tourist satisfaction model for a distinct destination that examines the effects of tourists' satisfaction antecedents such as service quality, perceived value, and destination

\footnotetext{
* Corresponding author
} 
image, as well as the consequences on tourists' revisit and word-of-mouth intentions. The structural equation modeling approach is used to validate the model, on which is based the Haor region of Bangladesh, a promising nature-based tourism destination. A Haor is a wetland biological system within the northeastern portion of Bangladesh, which physically is a bowl or saucer formed shallow sadness, know as a back swamp (CEGIS, 2012). During the monsoon, the Haors receive surface rain water from rivers and canals, resulting in large expanses of turbulent water. They turn into endless inland oceans in which towns present themselves as islands. Periodic strong winds amid the blustery season (July to December) create expansive waves within the Haor, which may cause impressive harm to homesteads. In any case, they all but dry up within the postmonsoon period. In the winter, these Haors have become endless extensions of the green world (CEGIS, 2012).

\section{HISTORICAL BACKGROUND AND HYPOTHESES}

The foremost reason for this study was to create and test a theoretical model, which spoke about the components contributing to the tourists' intent to return and word of mouth regarding the destination's brand, service quality, perceived value, and satisfaction are all aspects to remember. A brief outline of the interrelationship of constructs and the theoretical model is discussed.

\section{Destination Service Quality}

Service efficiency has been identified as a critical element in maintaining destination viability in the highly competitive tourism industry (Canny, 2013). Service quality is the result of the assessment handle where buyers compare desires with the administrations' reality, which is felt and acknowledged (Lai and Hitchcock, 2016). Interpretations of quality service in the service sector focus on assembling consumers' demands and requirements, as well as how well the benefit delivered meets customers' expectations (Berry et al., 1983). Service quality can also be recognized as the aspirations of customers who received and saw perceived services from a particular place (Kuo et al., 2009). Many scholars have examined the indirect relationships among service quality, perceived value, satisfaction, and revisit intention. For example, Woodruff (1977) stated that service quality was a significant antecedent to customer satisfaction, perceived value, and repurchase intention. Chang and Wildt (1994) also indicated that perceived quality obligated a robust and positive influence on perceived value. Therefore, we projected the subsequent hypotheses in the setting of a tourist destination:

Hypothesis 1: Destination service quality (SQ) positively affects tourist perceived value (PV)

Hypothesis 2: Destination service quality (SQ) positively affects tourist satisfaction (TS)

\section{Destination Image}

In general, people's views, emotions, and experiences about a region or area are referred to as destination image (Ilban et al., 2015). Image is moreover an expression of an individual's knowledge, foresight, dreams, and feelings (Baloglu and Brinberg, 1997). Crompton (1979) defines destination image as a human attitudinal concept made up of the convictions, thoughts, and impressions that a traveler holds of any potential destination. Many studies have been carried out regarding destination image, perceived value, and tourists' satisfaction for example Ozturk and Qu (2008) state that destination image has a significant effect on tourists' perceived value and tourists' expectations and eagerly suggest the destination to others. Wang et al. (2009) identified that the destination image worked out the most grounded total effect on tourist satisfaction. Therefore, we projected the subsequent hypotheses in the setting of a destination image:

Hypothesis 4: The destination image (DI) has a favorable effect on perceived value (PV)

Hypothesis 5: The destination image (DI) has a favorable effect on tourist satisfaction (TS)

\section{Perceived Value}

Perceived value is a component of a relationship which promotes a two-part design: one portion comprises the benefits gotten by the customer, whereas the other piece is composed of the sacrifices made by the customer (Cronin et al., 1997; Cronin et al., 2000). Gregory (1990, p.701) underlined the citation of William James: "part of what we perceive comes through our senses from the object before us; another part always comes out of our head." So, the tourist perception is impacted by the things which encompass him and the things the traveler has in his intellect. Perceived value is defined as "the consumer's overall assessment of the utility of a product or service based on perceptions of what is received and what is given" (Zeithaml, 1988, p.14). Perceived values and satisfaction are precedents for behavioral motivations uncovered by previous scholars through their research studies (Chen and Tsai, 2007; McDougall and Levesque, 2000; Parasuraman and Grewal, 2000; Petrick, 2004; Moral-Cuadra et al., 2019). Different researchers state that perceived value has a direct, positive association with tourist satisfaction (Wang et al., 2009; Eze et al., 2020). Therefore, we projected the subsequent hypotheses in the setting of a tourist perceived value:

Hypothesis 3: The higher the perceived value (PV), the higher the tourist satisfaction (TS)

\section{Tourists' Satisfaction}

Satisfaction is the feeling to which customer expectations from the product or services matched the prevailing quality (Žabkar et al., 2010). So, when a customer's expectations are felled by the quality of the product or services, the customer is fully satisfied. Besides, better than average benefit quality is not only planning to fulfill the sightseers, but it too progresses the destination image, splits the goal from others, and constructs a steadfast traveler to carry out a meticulous revisit behavior as a return to and positive word of mouth (Canny, 2013). 


\section{Revisit Intention}

The concept of revisiting the plan emerges from behavioral intentions. Several studies have finished realizing the constructive relationship and impact among tourist satisfaction, revisit, and word of mouth intentions (Adinegara, 2018; Padlee et al., 2019; Khuong and Nguyen, 2017; Canny, 2013), and researchers showed that when tourists are satisfied regarding the destination, then they repeat the visit. It is expressed that there's a positive relationship between tourist satisfaction and their aim to revisit the destination (Lee et al., 2011). Besides, the enjoyment of tourists may contribute to the purpose of revisiting or making satisfactory remarks on the destination to other visitors (Chi and Qu, 2008). Dissatisfied travelers could make unfavorable comments about the destination, damaging the customer reputations of the destinations (Reisinger and Turner, 2003a).

\section{Word of Mouth}

One of the multifaceted markers of behavioral intentions is Word of Mouth. Word of mouth is a casual communication, which is well-thought-out to be noncommercial, individual to an individual interface (Arndt, 1967). Tax et al. (1993) defined two effects of WOM. First, WOM activates a WOM recipient's behavioral purpose and potential actions. Second, a WOM receiver can transmit the data to others and influence their way of making decisions. Therefore, in the sense of tourist satisfaction, revisit intention, and Word of Mouth, we predicted the following hypotheses:

Hypothesis 6: Tourist satisfaction (TS) positively affects tourists' revisit intention (RI)

Hypothesis 7: Tourist satisfaction (TS) positively affects tourists' word of mouth intention (WOM)

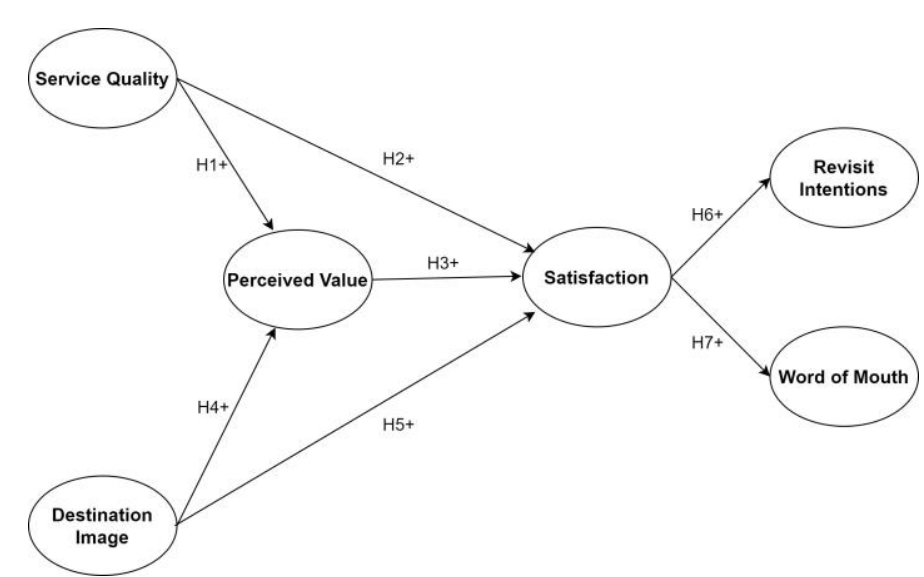

Figure 1. Conceptual model for tourists' satisfaction on the nature-based destination

\section{RESEARCH METHODOLOGY}

\section{Research Design}

To confirm the validity and reliability of the survey instrument, we utilized established measures from past pieces of literature where conceivable. The designated dimension indicators are related to the relevance of this research. Minor alterations were made to the estimation scales to guarantee reasonableness for the setting. Here we considered six latent variables consisting of two exogenous variables, namely service quality, and destination image.

Table 1. Variables name, Constructs, Measurement Items, Squared Multiple Correlation, Mean, Standard Deviation, and sources

\begin{tabular}{|c|c|c|c|c|c|}
\hline Variables & & Constructs and Measurement Items & \begin{tabular}{|c|}
$\begin{array}{c}\text { Squared Multiple } \\
\text { Correlation }\end{array}$ \\
\end{tabular} & Mean & \begin{tabular}{|l}
$\begin{array}{l}\text { Standard } \\
\text { Deviation }\end{array}$ \\
\end{tabular} \\
\hline \multirow{5}{*}{$\begin{array}{l}\text { Service Quality } \\
\text { (Narayan et al., 2008; } \\
\text { Tosun et al., 2015) }\end{array}$} & SQ1 & Tourist information at tourist spot is available & & 4.56 & 1.635 \\
\hline & SQ2 & This place's cleanliness of accommodation suits my needs & .567 & 4.12 & 1.613 \\
\hline & SQ3 & I feel the cleanliness and hygiene of restaurants is enough & & 3.77 & 1.614 \\
\hline & SQ4 & Overall cleanliness and hygiene at tourist spots is plenty & .652 & 4.08 & 1.647 \\
\hline & SQ5 & In this place, the hygiene level of food is ok & .449 & 4.24 & 1.693 \\
\hline \multirow{5}{*}{$\begin{array}{l}\text { Destination Image } \\
\text { (Chi and Qu 2008; } \\
\text { Beerli and Martin, 2004; } \\
\text { Phillips et al., 2011; } \\
\text { Tosun et al., 2015) }\end{array}$} & DI1 & It has a stunning and diverse natural environment & & 6.24 & 1.036 \\
\hline & DI2 & There is more than enough fresh, oxygen-rich air & .560 & 6.32 & .988 \\
\hline & DI3 & This place Haor is exciting & .663 & 6.16 & 1.100 \\
\hline & DI4 & This place Haor is a pleasant tourist destination & .584 & 5.96 & 1.109 \\
\hline & DI5 & This place is a good place for relaxation & .638 & 6.15 & 1.006 \\
\hline \multirow{4}{*}{$\begin{array}{l}\text { Perceived Value } \\
\text { (Kim, 2010; Gallarza et } \\
\text { al., 2013; Wang et al., } \\
\text { 2009) }\end{array}$} & PV1 & I feel It was my right decision to visit Haor & .572 & 6.07 & 1.026 \\
\hline & PV2 & My spending money is priced in this area & .533 & 5.85 & 1.075 \\
\hline & PV3 & I think, my spend time valued to visit Haor & .742 & 5.98 & 1.029 \\
\hline & PV4 & I believe, my effort to visit Haor is valued & .671 & 5.86 & 1.045 \\
\hline \multirow{5}{*}{$\begin{array}{l}\text { Satisfaction } \\
\text { (Canny, 2013; Gallarza } \\
\text { et al., 2013; Wang et } \\
\text { al., 2009; Ryu et al., } \\
\text { 2012; Marinao, 2018) }\end{array}$} & Sat1 & This place fulfills my expectations & .658 & 5.62 & 1.241 \\
\hline & Sat2 & I am satisfied with my decision to visit the Haor & .743 & 5.85 & 1.140 \\
\hline & Sat3 & My decision to visit this place was wise. & & 5.71 & 1.237 \\
\hline & Sat4 & This is the best place I have visited & & 4.97 & 1.497 \\
\hline & Sat5 & This place is exactly what I imagined & .469 & 5.31 & 1.339 \\
\hline \multirow{3}{*}{$\begin{array}{l}\text { Revisit Intention (Kim, } \\
\text { 2010; Gallarza et al., } \\
\text { 2013; Tosun et al., 2015) }\end{array}$} & RI1 & I want to visit back Haor next year & .712 & 5.14 & 1.565 \\
\hline & RI2 & I would like to revisit Haor shortly & .796 & 5.30 & 1.456 \\
\hline & RI3 & I would more frequently visit Haor & .531 & 4.93 & 1.532 \\
\hline \multirow{4}{*}{$\begin{array}{l}\text { Word of Mouth } \\
\text { (Kim, 2010; Canny, } \\
\text { 2013) }\end{array}$} & WOM1 & I will highly recommend Haor to others & .711 & 5.65 & 1.201 \\
\hline & WOM2 & I will tell others great things about Haor & .721 & 5.93 & 1.040 \\
\hline & WOM3 & I will encourage others who want advice for travel destination about Haor & .674 & 5.78 & 1.060 \\
\hline & WOM4 & I will tell others something good about my visit to Haor. & .587 & 5.96 & .978 \\
\hline
\end{tabular}

Note: A seven-point Likert scale has been used to evaluate the objects, ranging from strongly disagree (1) to strongly agree (7) 
On the other hand, four endogenous variables namely perceived value, satisfaction, word of mouth, and revisit intention. The questionnaire includes the respondents' demographic background and 26 measures for the constructs, five of which projected to measure tourists' feelings of the destination's service quality were derived from tourism literature (Narayan et al., 2008; Tosun et al., 2015). Besides, five of them were associated with destination image taken from (Chi and Qu, 2008; Beerli and Martin, 2004; Phillips et al., 2011; Tosun et al., 2015); perceived value allied constructs were four derived from (Kim, 2010; Gallarza et al., 2013; Wang et al., 2009), tourists' satisfaction linked constructs were five taken from (Canny, 2013; Gallarza et al., 2013; Wang et al., 2009; Ryu et al., 2012; Marinao, 2018). Consequently, four constructs were proposed to measure tourist's revisit intention were derived (Kim, 2010; Gallarza et al., 2013; Tosun et al., 2015), and four constructs were incorporated to measure tourists' word of mouth taken from the literature (Kim, 2010; Canny, 2013). The designated 26 constructs were rated on 7 points Likert scale where $1=$ strongly disagree (SD), and $7=$ strongly agree (SA). The constructs can be found in the Table 1. A pilot study with 30 respondents who visited the Haor area was conducted to test the questionnaire items' internal reliability and validity. Cronbach's alpha reliability coefficient was calculated, and as per the result, there was no need to remove any of the questions from the questionnaire. The Cronbach's alpha reliability coefficient of all the seven dimensions determined by the pretest was higher than 0.7 , indicated the right scale reliability (Nunnally and Bernstein, 1994). After finishing the pilot study, the final survey was performed and a total of 332 completed samples were collected. After reviewing invalid responses and achieving multivariate normality and considering outliers 40 samples were eliminated, and finally, 292 samples were taken for the study.

\section{Sample and data collection:}

The empirical research was conducted in one of the nature-based tourist spots Haor areas of Bangladesh. For the research, data has been collected only from domestic tourists through a structured questionnaire. Data were collected between September 2019 and September 2020. However, at times, data collection is hampered by COVID 19 pandemic conditions. So, from September to December 2019, some information has been collected by traveling to the Haor area and some information has been collected through Facebook by creating a questionnaire in Google form.

Applying the convenient sampling technique, a total number of 160 respondent's data were collected on the spot from those tourists who already visited the Haor area. On the other hand, 700 Google form questionnaire links were sent to the tourist through Facebook and 172 responses were received. Respondents were those visitors who have visited the Haor region over the last three years. A total of 332 completed samples were received and finally, 292 samples were taken for the study and this number of samples is adequate for SEM analysis.

\section{Profile of Respondents}

Table 2 describes $82.5 \%$ of respondents as males and $17.5 \%$ as females. This presents the fact that it is the male travelers who travel the region the most. Considering the marital status, it was found that $76.6 \%$ of the respondents were unmarried and $23.4 \%$ were married. On the other hand, the researcher found that $61.9 \%$ of respondents were between the ages of $16-25$ were young and ages $26-35$ were $26.8 \%$ and only $1.4 \%$ were $56+$. Most of the respondents have a graduation degree which is about $62.9 \%$, and a post-graduation degree of $28.2 \%$. How many times have you visited the Haor region? The answer to this question is that $60.5 \%$ of the respondents visited for the first time and $20.9 \%$ of the respondents visited for the second time.

Table 2. Respondents Profile (Source: Survey results)

\begin{tabular}{|c|c|c|c|c|}
\hline No. & Description & Classification & Frequency & $\%$ \\
\hline 1. & Gender & Female & 51 & 17.5 \\
\hline & & Male & 240 & 82.5 \\
\hline 2. & $\begin{array}{c}\text { Marital } \\
\text { Status }\end{array}$ & Married & 68 & 23.4 \\
\hline & & Single & 223 & 76.6 \\
\hline 3. & Age & $16-25$ & 180 & 61.9 \\
\hline & & $26-35$ & 78 & 26.8 \\
\hline & & $36-45$ & 22 & 7.6 \\
\hline & & $46-55$ & 7 & 2.4 \\
\hline & & $56+$ & 4 & 1.4 \\
\hline 4. & Education & Graduation & 183 & 62.9 \\
\hline & & HSC & 25 & 8.6 \\
\hline & & Post-Graduation & 82 & 28.2 \\
\hline & & SSC & 1 & .3 \\
\hline 5. & $\begin{array}{c}\text { Frequency } \\
\text { Visit Haor }\end{array}$ & 2 times & 60 & 20.6 \\
\hline & & 3 times & 15 & 5.2 \\
\hline & & For the first time & 176 & 60.5 \\
\hline & & $\begin{array}{c}\text { More than 3 } \\
\text { times }\end{array}$ & 40 & 13.7 \\
\hline
\end{tabular}

Table 3. CFA for the estimation model as a whole ( $\mathrm{N}=292)$ (Source: SEM results)

\begin{tabular}{|c|c|c|c|c|c|c|}
\hline Variables & Items & \begin{tabular}{|c|} 
Factor \\
Loading \\
\end{tabular} & \begin{tabular}{c|}
$\mathrm{T}-$ \\
Value \\
\end{tabular} & $\begin{array}{c}\text { Cronbach's } \\
\text { alpha }\end{array}$ & \begin{tabular}{|c|} 
Construct \\
Reliability (C.R) \\
\end{tabular} & $\begin{array}{c}\text { Average Variance } \\
\text { Extracted (AVE) }\end{array}$ \\
\hline \multirow{3}{*}{$\begin{array}{l}\text { Service } \\
\text { Quality }\end{array}$} & SQ2 & .753 & 10.863 & \multirow{3}{*}{.785} & \multirow{3}{*}{0.789} & \multirow{3}{*}{0.556} \\
\hline & SQ4 & .808 & Fixed & & & \\
\hline & SQ5 & .670 & 10.142 & & & \\
\hline \multirow{4}{*}{$\begin{array}{l}\text { Destination } \\
\text { Image }\end{array}$} & DI2 & .748 & 13.700 & \multirow{4}{*}{.861} & \multirow{4}{*}{0.863} & \multirow{4}{*}{0.611} \\
\hline & DI3 & .814 & Fixed & & & \\
\hline & DI4 & .764 & 14.073 & & & \\
\hline & DI5 & .799 & 14.873 & & & \\
\hline \multirow{4}{*}{$\begin{array}{l}\text { Perceived } \\
\text { Value }\end{array}$} & PV1 & .756 & 15.124 & \multirow{4}{*}{.871} & \multirow{4}{*}{0.871} & \multirow{4}{*}{0.629} \\
\hline & PV2 & .730 & 14.356 & & & \\
\hline & PV3 & .861 & Fixed & & & \\
\hline & PV4 & .819 & 17.113 & & & \\
\hline \multirow{3}{*}{ Satisfaction } & SAT1 & .811 & Fixed & \multirow{3}{*}{.822} & \multirow{3}{*}{0.831} & \multirow{3}{*}{0.623} \\
\hline & SAT2 & .862 & 16.077 & & & \\
\hline & SAT5 & .685 & 12.200 & & & \\
\hline \multirow{3}{*}{$\begin{array}{l}\text { Revisit } \\
\text { Intention }\end{array}$} & RI1 & .844 & Fixed & \multirow{3}{*}{.859} & \multirow{3}{*}{0.863} & \multirow{3}{*}{0.680} \\
\hline & RI2 & .892 & 16.963 & & & \\
\hline & RI3 & .729 & 13.663 & & & \\
\hline \multirow{4}{*}{$\begin{array}{l}\text { Word of } \\
\text { Mouth }\end{array}$} & WoM1 & .843 & Fixed & \multirow{4}{*}{.880} & \multirow{4}{*}{0.892} & \multirow{4}{*}{0.673} \\
\hline & WoM2 & .849 & 17.154 & & & \\
\hline & WoM3 & .821 & 16.371 & & & \\
\hline & WoM4 & .766 & 12.904 & & & \\
\hline
\end{tabular}




\section{Empirical Results}

\section{Assessment of the measurement model}

In this research, the unidimensionality of each variable was checked by Confirmatory factor analysis (CFA) (Figure 2). The validity and reliability of indicators are determined through investigators by Unidimensionality. For each factor, Table 3 displays the Factor Loading, T-Value, Cronbach's alpha, Construct Reliability (CR), and Average Variance Extracted (AVE) values. The result of the validity test shows that all variables have greater Kaiser Meyer Olkin (KMO) values than 0.5 (Kaiser and Rice, 1974). From reliability, the test shows that the Cronbach alpha value of each construct is more than the minimum of 0.70 cited (Hair et al., 2010) and for all constructs, Cronbach's alpha values displayed high internal consistency ranging from 0.785 to 0.880 . Service quality consists of 5 indicators and after calculating CFA, there are two indicators with a value that is less than 0.5 and eliminated, thus, the remaining three indicators are qualified unidimensionality. On the other hand, the destination image consists of five indicators. After CFA there is one indicator that has a value below 0.5 and eliminated, so the remaining four indicators have eligible unidimensionality.

The perceived value consists of four indicators and after CFA every indicator found eligible unidimensionality. Satisfaction consists of five indicators and after CFA two indicators value found below 0.5 and eliminated. So, the remaining three indicators have eligible unidimensionality. Besides, at $\mathrm{p}<0.01$ significance level, all the t-value metrics associated with each of the critical ratios surpassed the critical value (2.58), ranging from 10.142 to 17.154 . The values of construct reliability (CR) were all well above the suggested 0.70 standards (Hair et al., 2014). Besides, the average variance extracted (AVE) exceeded the 0.50 threshold value (Hair et al., 2010). Additionally, Table 4 shows that the squares of the associations between the constructs were all smaller than the AVE values, indicating that discriminant validity was present (Fornell and larcker, 1981). As a consequence, it is reasonable to believe that all latent constructs achieve sufficient validity and reliability which are appeared in Tables 3 and 4.

Table 4. Discriminant validity

\begin{tabular}{|l|c|c|c|c|c|c|}
\hline Constructs & Revisit intention & Service quality & Destination image & Perceived value & Satisfaction & Word of mouth \\
\hline Revisit intention & $\mathbf{0 . 8 2 5}$ & & & & & \\
\hline Service quality & 0.394 & $\mathbf{0 . 7 4 6}$ & & & & \\
\hline Destination image & 0.434 & 0.203 & $\mathbf{0 . 7 8 2}$ & & & \\
\hline Perceived value & 0.544 & 0.312 & 0.821 & $\mathbf{0 . 7 9 3}$ & & \\
\hline Satisfaction & 0.639 & 0.472 & 0.709 & 0.810 & $\mathbf{0 . 7 9 0}$ & \\
\hline Word of mouth & 0.560 & 0.231 & 0.705 & 0.743 & 0.677 & $\mathbf{0 . 8 2 0}$ \\
\hline
\end{tabular}

Model fit indices: $\chi 2(173)=358.930, \mathrm{GFI}=0.894, \mathrm{AGFI}=0.859, \mathrm{CFI}=0.950, \mathrm{NFI}=0.908, \mathrm{IFI}=0.950$, $\mathrm{TLI}=0.931$, RMSEA $=0.061$. Note: The square root of AVEs is defined by bold diagonal values.



Figure 2. Measurement Model

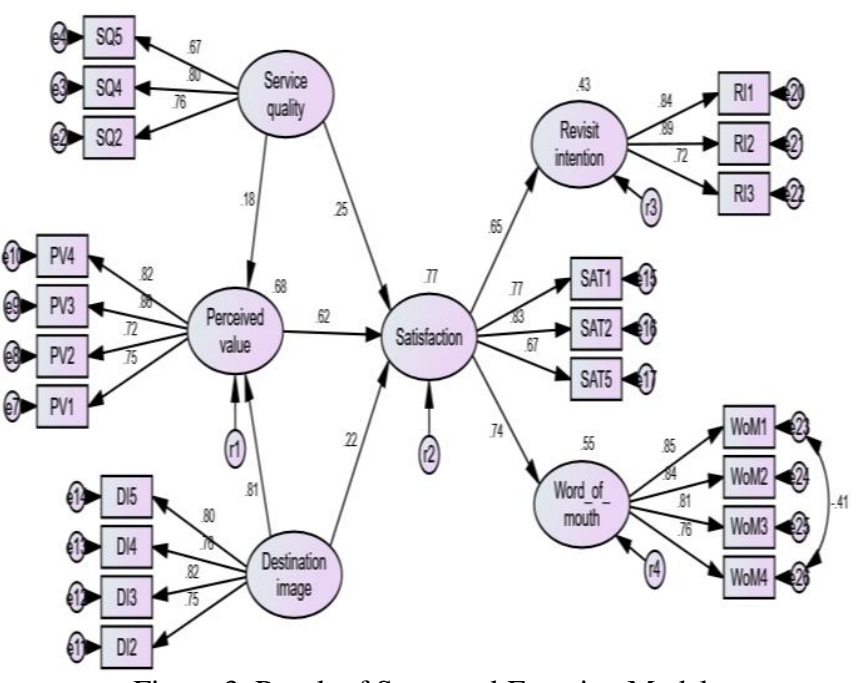

Figure 3. Result of Structural Equation Model

Table 5. Model Fit Measures for Structured Model (Source: Gaskin and Lim (2016) AMOS 24 Plugin output)

\begin{tabular}{|l|c|c|c|}
\hline \multicolumn{1}{|c|}{ Measure } & Estimate & Threshold & Interpretation \\
\hline CMIN & 419.274 & -- & -- \\
\hline DF & 181.000 & -- & -- \\
\hline CMIN/DF & 2.316 & Between 1 and 3 & Excellent \\
\hline CFI & 0.936 & $>0.95$ & Acceptable \\
\hline SRMR & 0.078 & $<0.08$ & Excellent \\
\hline RMSEA & 0.067 & $<0.06$ & Acceptable \\
\hline PClose & 0.000 & $>0.05$ & Not Estimated \\
\hline
\end{tabular}


The overall utility of the measurement model was calculated using the maximum likelihood estimation method. The findings of the confirmatory factor analysis (CFA) indicate that the calculation process has a high degree of model accuracy, as seen in Table 4. The fit indices data: $\chi 2(173)=358.930, p<0.001$, CMIN/DF, 2.075, Goodness-of-fit index $(\mathrm{GFI})=0.894$, Adjusted goodness of fit index $(\mathrm{AGFI})=0.859$, Normed-. Fit Index $(\mathrm{NFI})=0.908$, Incremental fit index $(\mathrm{IFI})=0.950$, Tucker-Lewis index $(\mathrm{TLI})=0.931$, Comparative fit index $(\mathrm{CFI})=0.950$, Standardized Root Mean Square Residual $(\mathrm{SRMR})=0.045$, Root mean- square error of approximation $(\mathrm{RMSEA})=0.061$.

\section{Assessment of the structural model}

Prior to calculating route coefficients for the hypothesized structural model, a structural model with six constructs was calculated utilizing maximum likelihood estimation (Figure 3). Table 5 shows that the SEM model exhibits a good level of model fit: $\chi 2(181)=419.274, p<0.001$, CMIN/DF, 2.316, Goodness-of-fit index $(\mathrm{GFI})=0.881$, Adjusted goodness of fit index $(\mathrm{AGFI})=.848$, Normed-. Fit Index $(\mathrm{NFI})=0.893$, Incremental fit index $(\mathrm{IFI})=0.936$, Tucker-Lewis index $(\mathrm{TLI})=$ 0.925, Comparative fit index $(\mathrm{CFI})=0.936$, Standardized Root Mean Square Residual $(\mathrm{SRMR})=0.078$, Root mean- square error of approximation $(\mathrm{RMSEA})=0.067$.

\section{Hypothesis examination results}

The purpose of this study was to show the tourists' satisfaction in the nature-based tourist destination and explores the relationship among destination image, service quality, perceived value, tourist satisfaction, word of mouth, and revisit intention of domestic tourist. The study showed some specific correlations through SEM analysis using software AMOS version 23 and result of six hypothesis (H1, H2, H3, H4, H6 and H7) are statistically significant (Table 6).

Table 6. Summary of outcomes of hypothesis tests

\begin{tabular}{|c|l|c|c|c|c|c|c|}
\hline H & \multicolumn{1}{|c|}{ Hypothesis } & Relationship & Estimate $(\beta)$ & $\begin{array}{c}\text { Standard } \\
\text { error }\end{array}$ & $\begin{array}{c}\mathrm{t}- \\
\text { statistics }\end{array}$ & $\mathrm{P}$ & Result \\
\hline $\mathrm{H} 1$ & $\begin{array}{l}\text { Destination service quality (SQ) positively affects tourist } \\
\text { perceived value (PV) }\end{array}$ & $\mathrm{SQ} \rightarrow \mathrm{PV}$ & 0.103 & .030 & 3.499 & $* * *$ & Supported \\
\hline $\mathrm{H} 2$ & $\begin{array}{l}\text { Destination service quality (SQ) positively affects tourist } \\
\text { satisfaction (TS) }\end{array}$ & $\mathrm{SQ} \rightarrow \mathrm{TS}$ & 0.176 & .037 & 4.760 & $* * *$ & Supported \\
\hline $\mathrm{H} 3$ & $\begin{array}{l}\text { The higher the perceived value (PV), the higher the } \\
\text { tourist satisfaction (TS) }\end{array}$ & $\mathrm{PV} \rightarrow \mathrm{TS}$ & 0.757 & .130 & 5.813 & $* * *$ & Supported \\
\hline $\mathrm{H} 4$ & $\begin{array}{l}\text { Destination image (DI) positively affects perceived value } \\
\text { (PV) }\end{array}$ & $\mathrm{DI} \rightarrow \mathrm{PV}$ & 0.739 & .070 & 10.539 & $* * *$ & Supported \\
\hline $\mathrm{H} 5$ & $\begin{array}{l}\text { Destination image (DI) positively affects tourist } \\
\text { satisfaction (TS) }\end{array}$ & $\mathrm{DI} \rightarrow \mathrm{TS}$ & 0.242 & .107 & 2.252 & .024 & Rejected \\
\hline $\mathrm{H} 6$ & $\begin{array}{l}\text { Tourist satisfaction (TS) positively affects tourist revisit } \\
\text { intention (RI) }\end{array}$ & $\mathrm{TS} \rightarrow \mathrm{RI}$ & 0.910 & .094 & 9.663 & $* * *$ & Supported \\
\hline $\mathrm{H} 7$ & $\begin{array}{l}\text { Tourist satisfaction (TS) positively affects tourist word } \\
\text { of mouth (WOM) }\end{array}$ & $\mathrm{TS} \rightarrow \mathrm{WOM}$ & 0.794 & .071 & 11.165 & $* * *$ & Supported \\
\hline
\end{tabular}
Notes: $* * * \mathrm{p}<0.001$

In particular, destination service quality positively affects tourist perceived value $(\mathrm{H} 1: \beta=0.103, \mathrm{t}=3.499$, $\mathrm{p}<$ $0.001)$, and destination service quality positively affects tourist satisfaction $(\mathrm{H} 2: \beta=0.176, \mathrm{t}=4.760, \mathrm{p}<0.001)$, and the higher the perceived value, the higher the tourist satisfaction $(\mathrm{H} 3: \beta=0.757, \mathrm{t}=5.813, \mathrm{p}<0.001)$.

Further, destination image positively affects perceived value $(\mathrm{H} 4: \beta=0.739, \mathrm{t}=10.539, \mathrm{p}<0.001)$, and tourist satisfaction positively affects tourist revisit intention $(\mathrm{H} 6: \beta=0.910, \mathrm{t}=9.663, \mathrm{p}<0.001)$, and tourist satisfaction positively affects tourist word of mouth intention $(\mathrm{H} 7: \beta=0.794, \mathrm{t}=11.165, \mathrm{p}<0.001)$.

However, one of the seven hypotheses was not supported, suggesting that there is no substantial association between destination image and tourist satisfaction $(\mathrm{H} 5: \beta=0.242, \mathrm{t}=2.252, \mathrm{p}$-value $=.024)$.

\section{DISCUSSION}

The findings revealed that the domestic tourists' reaction regarding nature-based destination service quality positively affects tourist perceived value (H1) and perceived value strengthens the tourist satisfaction (H3), these findings are close to the research carried out by Chang and Wildt (1994). It entails that domestic tourists' relative satisfaction improved as a result of the better treatment they received at nature-based destinations, and they were happy, resulting in economic gains for residents and businesses. Also, it is found that the destination service quality positively affects tourist satisfaction (H2) which is similar to the study findings of Woodruff (1977). The fourth hypothesis which is destination image positively affects perceived value -supported. According to the results, natural destination images in the mind of tourists directly impact the visitors' important experiences. However, the fifth hypothesis analysis result revealed that destination image didn't positively affect tourist satisfaction which is adverse to the results of Wang et al. (2009) and Chia et al. (2021). This result means proper service quality is needed to satisfy tourists and destination image is not directly connected to the satisfaction of tourists. But previous studies like Wang et al. (2009) and Chia et al. (2021) demonstrates there is a direct relationship between them and further study needed here.

The sixth hypothesis that is tourist satisfaction positively affects tourist revisit intention is supported and which is also revealed by the different researchers (Adinegara, 2018; Padlee et al., 2019; Khuong and Nguyen, 2017; Canny, 2013). 
Accordingly, H6 revealed that visitors' satisfaction and revisit intention are directly connected and suggests that local people and entrepreneurs should be concerned about tourists' satisfaction carefully and it ultimately enhance the destination's tourist quantity by ensuring revisit of the tourist. Besides, hypothesis seven - that tourist satisfaction positively affects tourist word of mouth is supported, which confirms the findings of Tax et al. (1993). It means satisfied tourists will talk more positively to others about what they have experienced and it will ultimately generate new tourist for the natural destination. These findings prove that tourists valued Haor travel and made the right decision to choose this nature based destination. Results demonstrate that, service quality and perceived value are considered to have a substantial effect on visitor satisfaction like as the work of Ramseook-Munhurrun et al. (2015). The higher the tourists' satisfaction ratings with the nature-based Haor destination, the more important their travel experiences are perceived to be, affecting their intentions to return and inclination to recommend the Haor destination.

In the sense of nature-based tourism, and tourists' behavioral intentions in relation to word-of-mouth and revisits, this study advances the usage of quality of destination services, image, and tourist satisfaction. This paper addresses the need expressed by many authors to examine in greater depth the forces influencing the formation of an image of a destination, the quality of service, and the perceived value, and to help fill the gap that exists between Bangladeshi domestic tourist and the theoretical development of tourist satisfaction, and revisitation and word-of-mouth intentions. The findings of this research support the use of a conceptual framework and the assessment of popular tourism quality experience of a multilayered and structured methodology such as the models established by several researchers (Wang et al., 2009; Ramseook-Munhurrun et al., 2015; Prayogo and Kusumawardhani, 2016; Adinegara, 2018; Khuong and Nguyen, 2017; Kim, 2010). Measurement model results demonstrate that all measurement methods for calculating experiential efficiency and proportions have a strong match model. Furthermore, the findings of reliability and validity studies show that the measurement units for calculating experiential consistency and measurements suggest satisfactory reliability and validity.

This research offers a conceptual basis for the dynamic links of six major constructs (quality of service, perceived value, image of destination, satisfaction of the tourists, desire to re-visit, and word-of-mouth). Firstly, the quality of service is checked empirically and proven to have an effect on the perceived value and happiness of visitors. The favorable association between service quality and perceived value and service quality and the satisfaction of tourists can be seen as the higher the quality of service perceived by tourists, the greater the perceived value and the satisfaction of tourists. Secondly, in this analysis, destination images are identified as having no positive impact on the happiness of visitors. This can be used as a destination image and is not a precedent of the pleasure of the visitor. Thirdly, the perceived value favorably affects the happiness of tourists and the greater the perceived value, the higher the satisfaction of tourists. Fourthly, the image of the destination affects the perceived value of tourists favorably, the greater the image of the destination, the higher the perceived value of tourists. Finally, visitor happiness positively affects the revisit of visitors and the intentions of word of mouth. The strong association between the revisit of tourists and word-of-mouth intentions can be translated as likely that naturalist tourists will repeat or return to nature after a high level of satisfaction in their minds.

For the tourism industry and public bodies, the findings of this research have real importance. Tour operators must provide positive experiences and emotions for visitors to form deep positive memories that will encourage them to return (Van-Dunem et al., 2021). Tourism industry stakeholders should look at the quality of the services of the destination and the satisfaction of the tourists. Stakeholders can work on the quality of services and collect reviews and, accordingly, they can reshape the services. Stakeholders can develop tourism goods and services in nature-based destinations in the future, thus improving the consistency of tourist experiences. These tourist experiences can be provided by service meetings, like the availability of information at tourist spots, cleanliness and hygiene of accommodation and food, stunning and diverse natural environment, and exciting, pleasant, relaxing environmental facilities and so on. Accumulate quality contributions from locals, businessmen, tourism companies, and government agencies result in proper tourist satisfaction and, eventually, an increase in favorable behavioral revisit and word-of-mouth intentions.

\section{CONCLUSION}

In conclusion, this study led to a deeper understanding of nature-based destinations by studying Haor, Bangladesh, and tourists' emotions, opinions, and behavioral intentions, as well as a guide on how to preserve and handle the production of high-quality services. This study has explored the relative contribution to tourist satisfaction and future revisit and word of mouth intentions of quality of service, perceived value and destination image.

The outcome has shown that the quality of service, perceived value and happiness of visitors have a huge bearing on the potential visitor and word-of-mouth intentions. The image of the building destination is different, not important to the relationship between the image of the destination and the happiness of the visitors.

The results show that the standard of service and perceived value is precedent of tourist satisfaction with nature and the behavioral aspirations of potential visitors are positively linked to the satisfactions of tourists. In the design and delivery of the service, perceived value for tourism actors has to be taken into account in accordance with the central and relational standard of services (McDougall and Levesque, 2000). Researchers need to integrate perceived value in models intended to consider the determinants of happiness and revisit of visitors and word of mouth intentions.

\section{Limitations and future research}

Even though this research may contribute to tourism practitioners and academics, there are some limitations. Here, only domestic tourists are considered as samples, whereas domestic and foreign tourists can be more correlated to measuring tourists' satisfaction. Due to the covid-19 pandemic situation, data collection from respondents through face 
to-face interviews has become a challenge. On the other hand, reaching foreign tourists for this purpose becomes impossible in a sense. This was a causal study, but the causal link in the model may be best interpreted by a longitudinal field study. In the future, a cross-sectional analysis of domestic and foreign tourists would be another direction. Furthermore, this research can be expanded to assess the effects of tourist demographics on the proposed model and extrapolated to other tourist and geographical contexts.

\section{REFERENCES}

Adinegara, G.N.J. (2018). Modeling of Tourist Satisfaction in Bali. Binus Business Review, 9(3), 261-276. https://doi.org/ 10.21512/bbr.v9i3.5019

Arndt, J. (1967). Role of Product-Related Conversations in the Diffusion of a New Product. Journal of Marketing Research, 4(3), 291295. https://doi.org/10.1177/002224376700400308

Baloglu, S., \& Brinberg, D. (1997). Affective Images of Tourism Destinations. Journal of Travel Research, 35(4), 11-15. https://doi.org/10.1177/004728759703500402

Beerli, A., \& Martín, J.D. (2004). Factors influencing destination image. Annals of Tourism Research, 31(3), 657-681. https://doi.org/10.1016/j.annals.2004.01.010

Berry, L.T., Shostak, L.G., \& Upah, G.D. (1983). Emerging Perspectives on Services Marketing. American Marketing Association, 99-107.

Buonincontri, P., Morvillo, A., Okumus, F., \& van Niekerk, M. (2017). Managing the experience co-creation process in tourism destinations: Empirical findings from Naples. Tourism Management, 62, 264-277. https://doi.org/10.1016/j.tourman.2017.04.014

Canny, I.U. (2013). An empirical investigation of service quality, tourist satisfaction and future behavioral intentions among domestic local tourist at Borobudur Temple. International Journal of Trade, Economics and Finance, 4(2), 86-91. https://doi.org/10.7763/ijtef.2013.v4.265

Chang, T.Z., \& Wildt, A.R. (1994). Price, product information, and purchase intention: An empirical study. Journal of the Academy of Marketing Science, 22, 16-27. http://doi.org/g7m

Chen, C.F., \& Tsai, D. (2007). How destination image and evaluative factors affect behavioral intentions? Tourism Management, 28(4), 1115-1122. https://doi.org/10.1016/j.tourman.2006.07.007

Chi, C.G.Q., \& Qu, H. (2008). Examining the structural relationships of destination image, tourist satisfaction and destination loyalty: An integrated approach. Tourism Management, 29(4), 624-636.

Chia, S.K.S., Lo, M.C., Razak, Z.B., Wang, Y.C., \& Mohamad, A.A. (2021). Impact of Destination Image on Tourist Satisfaction: The Moderating Effect of Information Technology (IT). Geojournal of Tourism and Geosites, 34(1), 88-93. https://doi.org/ 10.30892/Gtg.34112-623

Cong, L.C. (2016). A formative model of the relationship between destination quality, tourist satisfaction and intentional loyalty: An empirical test in Vietnam. Journal of Hospitality and Tourism Management, 50-62. https://doi.org/10.1016/j.jhtm.2015.12.002

Crompton, J.L. (1979). An Assessment of the Image of Mexico as a Vacation Destination and the Influence of Geographical Location Upon That Image. Journal of Travel Research, 17(4), 18-23. https://doi.org/10.1177/004728757901700404

Cronin Jr, J.J., Brady, M.K., \& Hult, G.T.M. (2000). Assessing the effects of quality, value, and customer satisfaction on consumer behavioral intentions in service environments. Journal of Retailing, 76(2), 193-218. https://doi.org/10.1016/S0022-4359(00)00028-2

Cronin Jr., J.J., Brady, M.K., Brand, R.R., Hightower Jr., R., \& Shemwell, D.J. (1997). A cross-sectional test of the effect and conceptualization of service value. Journal of Services Marketing, 11(6), 375-391. https://doi.org/10.1108/08876049710187482

Eze, F.J., Inyang, J.J., \& Orji, N.V. (2020). Determinants of Outbound Medical Tourism: Implications for Service Marketing and Development. Geojournal of Tourism and Geosites, 33(4), 1507-1512. https://doi.org/10.30892/gtg.334spl09-600

Fornell, C., \& Larcker, D.F. (1981). Evaluating structural equation models with unobservable variables and measurement error. Journal of Marketing Research, 18(1), 39-50. https://doi.org/10.2307/3151312

Gallarza, M.G., Gil Saura, I., \& Arteaga Moreno, F. (2013). The quality-value-satisfaction-loyalty chain: relationships and impacts. Tourism Review, 68(1), 3-20. https://doi.org/10.1108/16605371311310048

Gaskin, J., \& Lim, J. (2016). "Model Fit Measures", AMOS Plugin. Gaskination'sStatWiki, 1-55.

Gregory, R.L. (1990). Perceptions of William James-at the Centenary of The Principles of Psychology. Perception, 19(6), 701-704. https://doi.org/10.1068/p190701

Hair, J.F. Jr., Hult, G.T.M., Ringle, C.M., \& Sarstedt, M. (2014). A Primer on Partial Least Squares Structural Equation Modeling (PLSSEM), Sage Publications, ISBN: 978-1-4522-1744-4, 307.

Hair, J.F., Black, W.C., Babin, B.J., \& Anderson, R.E. (2010). Multivariate data analysis (7th Ed.). Upper Saddle River, NJ: Prentice Hall.

Hossain, E. (2013). An Investigation on Tourism Consumers' Choice Behavior Towards Tour Destination Loyalty. PhD's thesis, Curtin Business School, Curtin University, Curtin University. https://espace.curtin.edu.au/handle/20.500.11937/1026

Hossain, M.S., Chowdhury, M., \& LIPY, N.S. (2015). Exploratory Analysis of Tourists' Satisfaction Level on Tourism Goods and Services of Kuakata and Sundarbans, Bangladesh. Journal of Business Research, Faculty of Business Studies, Begum Rokeya University, Rangpur, Bangladesh, 1(1), 21.

Ilban, M.O., Kasli, M., \& Bezirgan, M. (2015). Effects of destination image and total perceived value on tourists' behavioral intentions: An investigation of domestic festival tourists. Tourism Analysis, 20(5), 499-510. https://doi.org/10.3727/108354215X14411980111370

Joppe, M., Martin, D.W., \& Waalen, J. (2001). Toronto's image as a destination: A comparative importance-satisfaction analysis by origin of visitor. Journal of Travel Research, 39(3), 252-260. https://doi.org/10.1177/004728750103900302

Kaiser, H.F., \& Rice, J. (1974). Little Jiffy, Mark IV. Educational and Psychological Measurement, 34(1), 111117. https://doi.org/10.1177/001316447403400115

Khuong, M.N., \& Nguyen, P.A. (2017). Factors Affecting Tourist Destination Satisfaction and Return Intention - A Study in Ho Chi Minh City, Vietnam. Journal of Economics, Business and Management, 5(2), 95-102. https://doi.org/10.18178/joebm.2017.5.2.493

Kim, S.N. (2010). Antecedents of destination loyalty. Doctoral dissertation, University of Florida. https://ufdc.ufl.edu/UFE0041512/00001

Kozak, M. (2001). Comparative assessment of tourist satisfaction with destinations across two nationalities. Tourism Management, 22(4), 391-401. https://doi.org/10.1016/s0261-5177(00)00064-9

Kuo, Y.F., Wu, C.M., \& Deng, W.J. (2009). The relationships among service quality, perceived value, customer satisfaction, and post-purchase intention in mobile value-added services. Computers in Human Behavior, 25(4), 887- 896. https://doi.org/10.1016/j.chb.2009.03.003 
Lai, I.K.W., \& Hitchcock, M. (2016). A comparison of service quality attributes for stand-alone and resort-based luxury hotels in Macau: 3Dimensional importance-performance analysis. Tourism Management, 55, 139-159. https://doi.org/10.1016/j.tourman.2016.01.007

Le, C.C., \& Dong, D.X. (2017). Factors affecting European tourists' satisfaction in Nha Trang city: perceptions of destination quality. International Journal of Tourism Cities, 3(4), 350-362. https://doi.org/10.1108/IJTC-04-2017-0022

Lee, S., Jeon, S., \& Kim, D. (2011). The impact of tour quality and tourist satisfaction on tourist loyalty: The case of Chinese tourists in Korea. Tourism Management, 32(5), 1115-1124. https://doi.org/10.1016/j.tourman.2010.09.016

Marinao, E. (2018). Determinants of Satisfaction with the Tourist Destination. Mobilities, Tourism and Travel Behavior - Contexts and Boundaries. Published. https://doi.org/10.5772/intechopen.70343

Mcdougall, G.H., \& Levesque, T. (2000). Customer satisfaction with services: putting perceived value into the equation. Journal of Services Marketing, 14(5), 392-410. https://doi.org/10.1108/08876040010340937

Moral-Cuadra, S., Orgaz-Agüera, F., \& Cañero-Morales, P.M. (2019). Attitude Towards Border Tourism and Its Relationship With Visitor Satisfaction and Loyalty. Geojournal of Tourism and Geosites, 25(2), 609-622. https://doi.org/10.30892/gtg.25226-384

Narayan, B., Rajendran, C., \& Sai, L.P. (2008). Scales to measure and benchmark service quality in tourism industry. Benchmarking: An International Journal, 15(4), 469-493. https://doi.org/10.1108/14635770810887258

Nunnally, J.C., \& Bernstein, I.H. (1994). Psychometric Theory. 3rd ed., McGraw-Hill, New York,NY.

Ozturk, A.B., \& Qu, H. (2008). The Impact of Destination Images on Tourists' Perceived Value, Expectations, and Loyalty. Journal of Quality Assurance in Hospitality \& Tourism, 9(4), 275-297. https://doi.org/10.1080/15280080802520552

Padlee, S.F., Thaw, C.Y., \& Atikah Zulkiffli, S.N. (2019). The relationship between service quality, customer satisfaction and behavioural intentions in the hospitality industry. Tourism and Hospitality Management, 25(1), 121-139. https://doi.org/10.20867/thm.25.1.9

Parasuraman, A., \& Grewal, D. (2000). The Impact of Technology on the Quality-Value-Loyalty Chain: A Research Agenda. Journal of the Academy of Marketing Science, 28(1), 168-174. https://doi.org/10.1177/0092070300281015

Petrick, J.F. (2004). Are loyal visitors desired visitors? Tourism Management, 25(4), 463-470. https://doi.org/10.1016/s0261-5177(03)00116-x

Phillips, W.M.J., Wolfe, K., Hodur, N., \& Leistritz, F.L. (2011). Tourist Word of Mouth and Revisit Intentions to Rural Tourism Destinations: a Case of North Dakota, USA. International Journal of Tourism Research, 15(1), 93-104. https://doi.org/10.1002/jtr.879

Prayogo, R.R., \& Kusumawardhani, A. (2016). Examining Relationships of Destination Image, Service Quality, e-WOM, and Revisit Intention to Sabang Island, Indonesia. Asia Pacific Management and Business Application, 5(2), 85-96. https://doi.org/ 10.21776/ub.apmba.2016.005.02.3

Rahaman, A. (2009). Development of tourism industry in Bangladesh: Issues and Strategies. PhD's thesis, University of Dhaka, Department of Marketing University of Dhaka, 133. http://repository.library.du.ac.bd/xmlui/bitstream/handle/123456789/1379/ Eumna\%20Bushra.pdf?sequence $=1$

Ramseook-Munhurrun, P., Seebaluck, V.N., \& Naidoo, P. (2015). Examining the Structural Relationships of Destination Image, Perceived Value, Tourist Satisfaction and Loyalty: Case of Mauritius. Procedia - Social and Behavioral Sciences, 175, $252-259$. https://doi.org/10.1016/j.sbspro.2015.01.1198

Reisinger, Y., \& Turner, L. (2003a). Cross-Cultural Behaviour in Tourism: concepts and analysis (1st ed.). Butterworth-Heinemann.

Ryu, K., Lee, H.R., \& Gon Kim, W. (2012). The influence of the quality of the physical environment, food, and service on restaurant image, customer perceived value, customer satisfaction, and behavioral intentions. International Journal of Contemporary Hospitality Management, 24(2), 200-223. https://doi.org/10.1108/09596111211206141

Tax, S.S., Chandrashekaran, M., \& Christiansen, T. (1993). Word-of-mouth in consumer decision-making: An agenda for research. Journal of Consumer Satisfaction, Dissatisfaction and Complaining Behavior, 6(10), 74-80.

Tosun, C., Dedeoğlu, B.B., \& Fyall, A. (2015). Destination service quality, affective image and revisit intention: The moderating role of past experience. Journal of Destination Marketing and Management, 4(4), 222-234. https://doi.org/10.1016/j.jdmm.2015.08.002

Van-Dunem, T., Coelho, A., \& Bairrada, C. (2021). International Tourist's Perception of the Destination Image: A Study Applied To Luanda, Angola. Geojournal of Tourism and Geosites, 35(2), 411-418. https://doi.org/10.30892/gtg.35220-667

Viet, B.N. (2019). The influence of destination image components on tourist satisfaction and loyalty: A case study in Côn Dao Islands, Vietnam. African Journal of Hospitality, Tourism and Leisure, 8(4), 1-14.

Wang, X., Zhang, J., Gu, C., \& Zhen, F. (2009). Examining Antecedents and Consequences of Tourist Satisfaction: A Structural Modeling Approach. Tsinghua Science and Technology, 14(3), 397-406. https://doi.org/10.1016/S1007-0214(09)70057-4

Woodruff, R.B. (1997). Customer value: The next source for competitive advantage. Journal of the Academy of Marketing Science, 25(2), 139-153. https://doi.org/10.1007/bf02894350

Yoon, Y., Gursoy, D., \& Chen, J.S. (2001). Validating a tourism development theory with structural equation modeling. Tourism Management, 22(4), 363-372. https://doi.org/10.1016/S0261-5177(00)00062-5

Žabkar, V., Brenčič, M.M., \& Dmitrović, T. (2010). Modelling perceived quality, visitor satisfaction and behavioural intentions at the destination level. Tourism Management, 31(4), 537-546. https://doi.org/10.1016/j.tourman.2009.06.005

Zeithaml, V.A. (1988). Consumer perceptions of price, quality and value: A means-end model and synthesis of evidence. Journal of Marketing, 52 (July), 2-22.

*** CEGIS. (2012). Master plan of haor area. Ministry of Water Resources, Government of the People's Republic of Bangladesh, I (April 2012), 1-82.

*** WTTC. (2020). Global economic impact \& trends 2020. June, 27. https://wttc.org/Research/Economic-Impact/moduleId/ 1445/itemId/91/controller/DownloadRequest/action/QuickDownload

\footnotetext{
Article history: Received: 19.04.2021 Revised: 06.07.2021 Accepted: 20.08.2021 Available online: 08.09.2021
} 